\title{
Eco-design of portable solar-powered telescopic lamp for off- grid areas in Indonesia
}

\author{
Kadek Heri Sanjaya ${ }^{1}$, Ahmad Rajani ${ }^{2}$, Hendri Maja Saputra ${ }^{3}$, Dalmasius Ganjar Subagio ${ }^{4}$, Ridwan \\ Arief Subekti ${ }^{5}$, Ahmad Fudholi ${ }^{6}$ \\ ${ }^{1-6}$ Research Centre for Electrical Power and Mechatronics, Indonesian Institute of Sciences (LIPI), Bandung 40135, \\ Indonesia \\ ${ }^{6}$ Solar Energy Research Institute, Universiti Kebangsaan Malaysia, 43600 Bangi Selangor, Malaysia
}

\begin{tabular}{|c|c|}
\hline Article Info & ABSTRACT \\
\hline Article history: & This study describes the development of eco-design of portable sol \\
\hline Received Apr 27, 2021 & $\begin{array}{l}\text { red telescopic lamp for off-grid area in Indonesia. Several design } \\
\text { ements for the lamp, namely, sustainability, portability, affordability, }\end{array}$ \\
\hline Revised Oct 13, 2021 & and reliability, are the objectives of the design process in this study. \\
\hline Accepted Oct 22, 2021 & $\begin{array}{l}\text { Sustainability is achieved through renewable energy and the application of } \\
\text { eco-design principles. Portability means it is lightweight, compact and can be }\end{array}$ \\
\hline Keywords: & $\begin{array}{l}\text { carried anywhere inside a tube. This solar-powered telescopic lamp was } \\
\text { designed with a } 3.7 \mathrm{~V}, 15.6 \text { Ah battery power specification such that the }\end{array}$ \\
\hline Eco-design & battery power is around $57.72 \mathrm{Wh}$. The optimal use of the battery is $80 \%$ of \\
\hline Off-grid & $\begin{array}{l}\text { the total battery power that is } 46.176 \mathrm{Wh} \text {. With a power of } 46,176 \mathrm{Wh} \text {, the } \\
\text { battery can turn on the LED strip light with a } 4.8 \mathrm{~W} \text { power specification for }\end{array}$ \\
\hline Photovoltaic & $9.62 \mathrm{~h}$. The test results showed that the telescopic lamp endurance met the \\
\hline Renewable energy & expected specifications. The real consumed power by the LED strips was \\
\hline Solar energy & around $1.9 \mathrm{~W}$. The charging test using solar panels with $12 \mathrm{Wp}$ specifications \\
\hline Telescopic lamp & $\begin{array}{l}\text { showed that it will be fully charged in around } 3.8 \mathrm{~h} \text {. However, the } \\
\text { performance of the telescopic lamp, especially in the charging process, is } \\
\text { affected by the environment condition, such as sunlight intensity, ambient } \\
\text { temperature, and humidity. }\end{array}$ \\
\hline
\end{tabular}

This is an open access article under the CC BY-SA license.

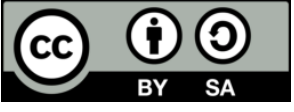

\section{Corresponding Author:}

Kadek Heri Sanjaya

Research Centre for Electrical Power and Mechatronics

Indonesian Institute of Sciences (LIPI)

Bandung 40135, Indonesia

Email: kade001@lipi.go.id

\section{INTRODUCTION}

While Indonesia's demand for electricity is growing, the country's electrification rate is low when compared to other ASEAN countries [1]. The cost of building and maintaining electricity networks in Indonesia is higher due to the country's geographical location as an archipelagic country vulnerable to natural disasters [2]. The low electrification ratio is partly due to the outdated idea of centralizing electricity generation and disseminating it through transmission lines. Furthermore, even though Indonesia has been a net importer of oil since 2004, many power plants still use fossil fuels, putting a greater strain on energy subsidies. As a result, there is an issue of energy supply sustainability in regional growth, where meeting current needs does not come at the expense of potential needs [3]. Renewable energy sources, such as solar energy, have evolved into a source of energy that benefits the environment. Photovoltaic (PV) systems transform solar energy into electric energy [4]. The application of PV systems offers the decentralization of power generation in the form of microgrids [5] or small standalone off-grid system [6], [7]. The use of 
renewable energy with the network of microgrids allows greater distribution of the system and increase the acceptability [8]. In a study in Thailand on the EV charging station based on renewable energy reported that charging cost by PV offered the lowest cost [9]. Encouraged by the advantages of the PV systems, in this study, a portable solar-powered lamp is developed. Table 1 lists the articles referred for background studies for developing the design requirements of the lamp.

Table 1. Overview of the included background studies

\begin{tabular}{|c|c|c|}
\hline Author(s) & Main information & $\begin{array}{l}\text { Implications to } \\
\text { study }\end{array}$ \\
\hline Statistics Indonesia [10] & Information on low electrification ratio in Indonesia and distribution & Background studies \\
\hline Fuad-Luke [11] & $\begin{array}{l}\text { Product design comparison: Metronimis, Nimbus, Osram Sylvania } \\
\text { Lumalux, and Street Light F solar-powered lamps }\end{array}$ & Design requirements \\
\hline Zhao et al. [12] & Product design comparison: portable solar-powered lightbox & Design requirements \\
\hline Wang [13] & Product design comparison: solar-powered lantern & Design requirements \\
\hline Bastian et al [14] & $\begin{array}{l}\text { Product design comparison: solar-powered portable emergency } \\
\text { lamp }\end{array}$ & Design requirements \\
\hline Snyder [15] & Product design comparison: inflatable solar-powered lamp & Design requirements \\
\hline McHenry et al [16] & Product design comparison: portable PV battery-LED systems & Design requirements \\
\hline Mubarok [17] & Problems in utilization of PV systems among novel users & Design requirements \\
\hline $\begin{array}{l}\text { Shimomura and } \\
\text { Katsuura [18] }\end{array}$ & Universal design principle for easy-to-use product design & Design requirements \\
\hline Mital et al [19] & Biomechanical requirements in a hand-carried products & Design requirements \\
\hline
\end{tabular}

In anthropology studies, the term "technostress" refers to a problem with the implementation of new technology that necessitates user adaptation [20]. Mental stress will occur when the human cognition system interacts with sophisticated new technology that necessitates a time-consuming learning process [21]. As a result, the universal design principle can be used to make the product easy to use by taking into account the cultural aspects of the potential users. Given that the solar-powered telescopic lamp would be used mostly in remote areas, it should be quick and easy to operate while also taking into account the lamp's sustainability, portability, and reliability. Considering that the product development period has become shorter nowadays [22], the conceptual product stage is combined with the functional analysis to skip several stages in product development. The concept of eco-design on the other hand should be considered not only during the design stage but also for the entire product lifecycle [23]. The lifecycle is started from design, raw materials, manufacturing, distribution, use and finished at the end-of-life of the product [23]. Other studies included the phases of re-use and recycling before the disposal [24], [25]. In the design stage, the last two stages of the design process are prototyping and the evaluation of the prototype through field experiments. In the technical aspect of the design requirements, the solar-powered lamp should be charged during the daytime to provide light for the entire night. To accomplish these goals, a thorough design process should be followed, as well as field tests. Furthermore, the lamp does not require a complex management system to operate as a stand-alone product.

\section{MATERIALS AND METHODS}

The telescopic lamp has a total weight of $2 \mathrm{~kg}$. The full height of the lamp is around $1.5 \mathrm{~m}$, and the collapsible height is $0.8 \mathrm{~m}$. The folded telescopic lamp can be carried by placing inside a drafting tube. The size of the telescopic lamp allows easier transportation given that the weight is far below the maximum carrying load of even females or children as suggested by manual material handling guidelines [19]. As illustrated in the design concept in Figure 1, the compact and lightweight design ensures greater efficiency in manufacturing, distribution, and use. The modular design where the tube and the solar panels can be assembled and disassembled means easier maintenance given that any parts that are broken can be replaced easily. The lamp is intended for users in remote areas where the population is mostly less educated. They have limited experience and access to advanced products. Thus, the technology incorporated into the lamp is the simplest ones. The assumption was that the simple and rugged design would make it easier to use and maintain.

The solar-powered telescopic lamp comprises four $12 \mathrm{~V}$ LED stripes arranged in circular surrounding the top of the telescopic rod, as shown in Figure 1. The parallel circuits of solar cells arranged on a rectangular sheet are placed above the top of the telescopic rod and held up by a supporting stand with four small rods connecting each corner of the rectangular sheet with the top of the telescopic rod. Other components, which include electronic charging devices, $3.7 \mathrm{~V}$ lithium 18650 batteries for energy storage and the power supply to turn on/off the electrical system, switch, indicator for charging condition, power 
indicator lights, USB connectors and electrical power jack, are all installed at the lower part of the telescopic rod. A small foldable tetrapod was added on the lowest part of the rod to support the lamp during standing.
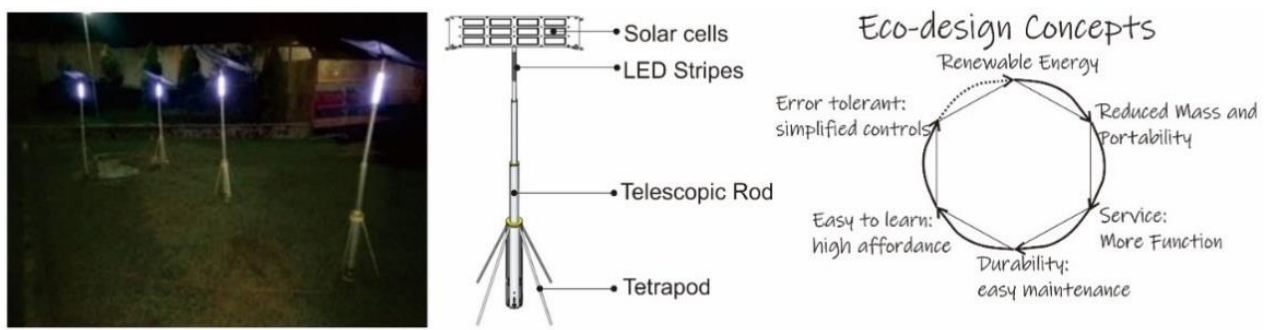

Figure 1. The field test of the lamp (left), isometric technical drawing of solar-powered telescopic lamp prototype (center), and eco-design concepts of the lamp where the use of renewable energy in the form of solar power is supported by other features such as lightweight, greater function, easy maintenance, and easy

to use (right)

The field testing of the solar-powered telescopic lamp was intended to be conducted in two opposite topographic areas: highland. The field testing with different location conditions was performed to validate the results of solar telescopic lamp design in real-life locations where the lamp was designed to be utilised. In this field test, Ciwidey and Lembang, in the mountainous area nearby Bandung in West Java Province, were selected for highland areas. Indonesia lies around the equator with a hot and humid tropical climate where only two seasons, namely, dry, and rainy seasons, occur with a relatively constant temperature. The mountain region has an average temperature of $23^{\circ} \mathrm{C}$ [26].

The field experiment was conducted in the dry season of 2020 due to several problems from the field experiment performed during the rainy season of 2018. The last field experiment was performed in Lembang, West Java. In the experiment, a stricter experiment procedure was conducted where the data were not only collected by a data logger but also by performing manual measurements using several instruments to confirm the results recorded in the data logger. The previous experiments showed that the data logger is prone to error, which is probably related to its exposure to the environment. The experiment procedure is illustrated in Figure 2. The experiment was performed only to measure the charging process. The stricter data recording procedure was implemented using the data logger and manual measurement using instruments such as voltmeter and amperemeter, as well as environmental variable measuring instruments. The information on the measurement instruments is provided in Table 2. The environmental variables measured were solar irradiance, ambient temperature, panel surface temperature and humidity. The voltage and the current were measured before and after the circuit to understand the efficiency. The field experiment was performed from 10:00 WIB to 16:00 WIB.

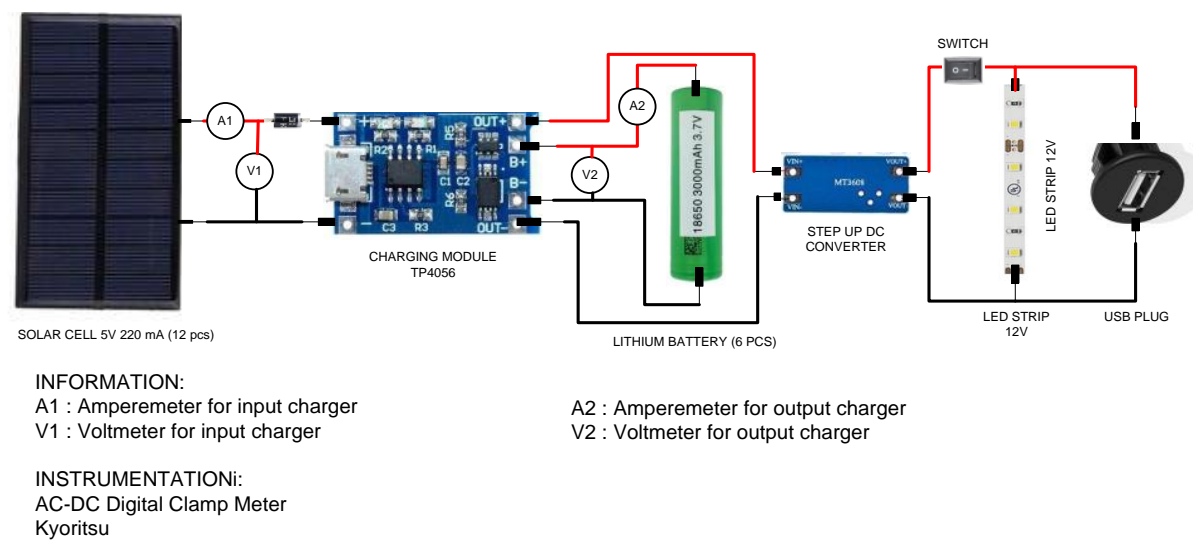

INSTRUMENTATION DRAWING ON TELESCOPIC LAMP TESTING

Figure 2. Schematic diagram of the field experiment. The voltmeter and the amperemeter were placed to measure both the input (before the circuit) and output (after the circuit) chargers 


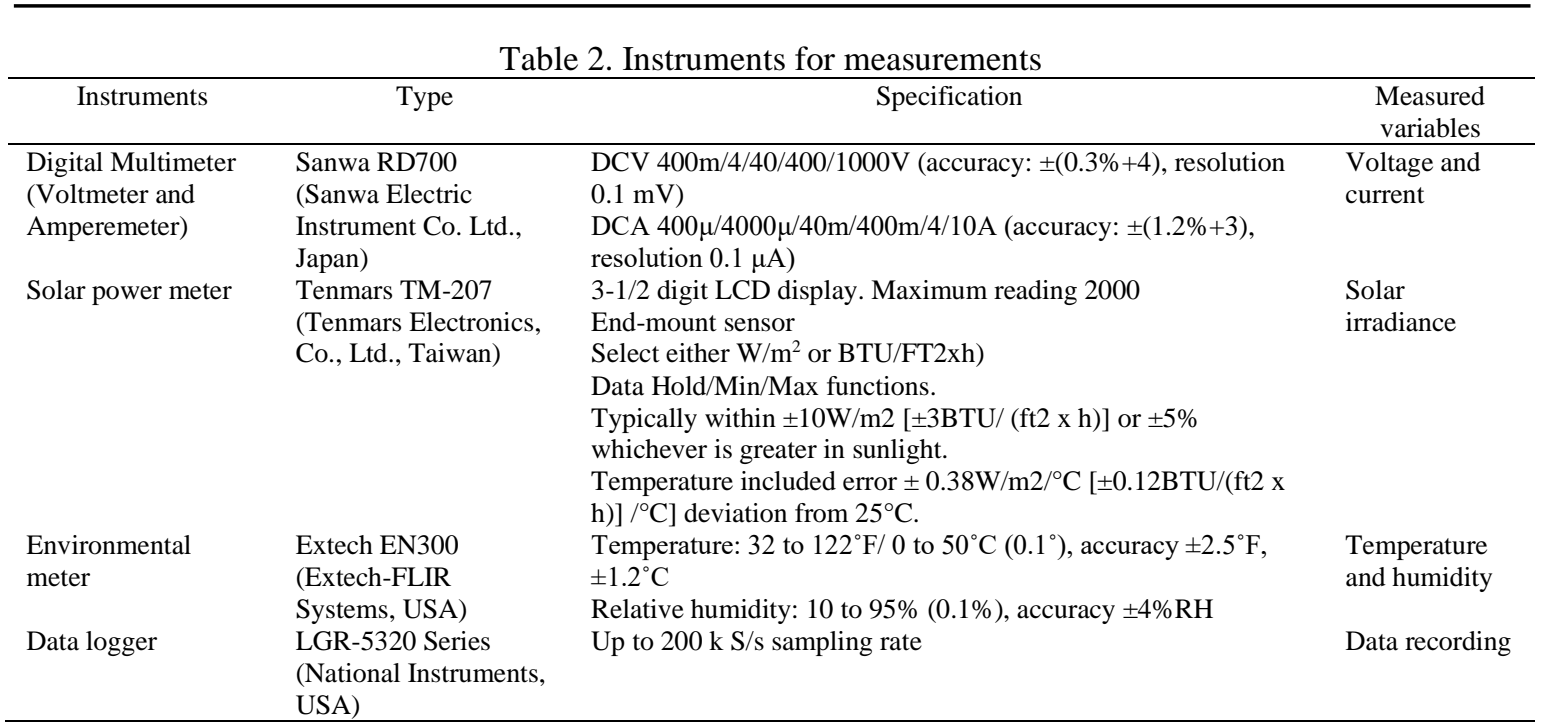

Several problems were experienced from the previous experiments that were performed during the rainy season. The data logger did not always work well to record the data on the performance of the solarpowered telescopic lamp during exposure in the field. The problems were confirmed when statistical analyses were conducted to measure the effects of environmental variables on the charging performance. The fourth field experiment at Lembang was conducted in August 2020 or during the dry season. The location is the same as that of the first experiment.

\section{EXPERIMENT RESULTS}

The results of field experiments provide insight into various aspects of the solar-powered telescopic lamp. From the first location of the field experiment to the last, several problems occurred. The most obvious was that, from a few prototypes tested, not all of them produced good data mostly because of data loggers' connection that made them failed to record data. Given that the timing of the field experiment was conducted at the beginning of the rainy season in November 2018, the weather conditions also created challenges for the experiment. The cloudy weather, which is common during the rainy season, has been suggested to reduce solar panel output up to around $80 \%$ [27]. To re-confirm this assumption, we conducted another field experiment focused on the charging process in the dry season of 2020 when the weather is relatively clear without excessive clouds that block sunlight.

\subsection{Weather condition during the field experiments}

The first location for conducting the field test was in the highlands of Cikole, Jayagiri, Lembang, a small-town north of Bandung, West Java, which situated on the slope of Mount Tangkuban Perahu. The geographic coordinate of the first field experiment location is $S=06^{\circ} 46^{\prime} 54.7^{\prime \prime} \mathrm{E}=107^{\circ} 38^{\prime} 59.5^{\prime \prime}$ at an altitude of $1,376 \mathrm{~m}$ above sea level. During the experiment for 2 days in Lembang, the weather was predominantly cloudy with light showers. The temperature was around $19^{\circ} \mathrm{C}$ in the morning to $25^{\circ} \mathrm{C}$ in midday. The humidity was around $90 \%$ in the morning when the weather was partly drizzle and around $70 \%$ in the afternoon when the weather was cloudy. Then, the humidity increased again to more than $80 \%$ before sunset when the weather showed light showers. Humidity has been reported to affect solar radiation reception and photovoltaic performance, where higher humidity increases solar power loss [28], [29]. The peak solar irradiance was 463-471 W/m² at around 9:00 Western Indonesia Time (Waktu Indonesia Barat/WIB) in the morning. Another experiment (the fourth one) was performed in Lembang during the dry season of 2020, with clear weather, greater solar irradiance and lower humidity than the first field experiment.

The second location for the field experiment was Ciwidey with geographical coordinates of $\mathrm{S}=07^{\circ} 06^{\prime} 46.6^{\prime \prime} \mathrm{E}=107^{\circ} 26^{\prime} 20.7^{\prime \prime}$ at an altitude of $1321 \mathrm{~m}$ above sea level. The field experiment at Ciwidey was conducted right after the experiment in Lembang in November 2018. The second field test location was nearly at the same characters as the first test location, which is in the highlands, given that Ciwidey is located on the slope of Mount Patuha, in the south of Bandung. Considering that the weather was clear, the temperature was slightly higher between $21^{\circ} \mathrm{C}$ in the morning to $28^{\circ} \mathrm{C}$ in midday, with the humidity between $57.8 \%$ and $77.1 \%$. The humidity was relatively lower than that in the field experiment in Lembang. The solar irradiance was $406-635 \mathrm{~W} / \mathrm{m}^{2}$ in the morning between 9:00 to 10:00 WIB. 


\subsection{First field experiment at Lembang, West Java}

In the first field experiment, five telescopic lamp prototypes were tested, out of which only two of them successfully produced data to be reported in this article. The testing of the solar-powered telescopic lamp 1 during day 2 began at 07:36 Western Indonesia Time (Waktu Indonesia Barat/WIB) in Lembang with an initial battery voltage of $3.49 \mathrm{~V}$ and the current of $462.8 \mathrm{~mA}$. The experiment was performed during the daytime and completed right before sunset. Thus, charging and discharging processes occurred simultaneously in this session. The telescopic lamp 1 was found to last for approximately $10 \mathrm{~h}$ with a remaining voltage of $3.34 \mathrm{~V}$ and a current of $314.1 \mathrm{~mA}$. The timing of the experiment during the daytime provided solar energy supply that prevented a fast energy draining. As illustrated in Figure 3 (a), the voltage and current changes in lamp 1 during the field test were relatively flat with a slight decrease. Yellow lines represent voltage, and dotted blue lines represent current. The simultaneous charging and discharging processes during greater solar irradiance prevented the fast energy draining, especially before afternoon. The lower solar irradiance in the afternoon resulted in the drastic drop of voltage and current in Figure 3 (b).

The field testing of the solar-powered telescopic lamp 2 during day 2 began at 6:15 WIB in Lembang with the initial voltage of the solar panel of $5.68 \mathrm{~V}$ and the current of $59.6 \mathrm{~mA}$. Similar to lamp 1, lamp 2 also underwent charging and discharging processes simultaneously in the test. The maximum voltage generated by the solar panel was $6.12 \mathrm{~V}$, and the maximum current was $134.1 \mathrm{~mA}$. The sunlight could be received optimally only until 13:00 WIB because the weather turned cloudy thereafter and was followed by showers that made the sunlight intensity dropped to only less than $10 \%$ compared with the peak intensity that was measured that day. The calculated efficiency of the circuit during the peak condition was around $25.59 \%$. The efficiency, which represents the circuit efficiency, was calculated based on the comparison of output and input powers [30]-[32]. The voltage and current changes in lamp 2 are shown in Figure 3 (b). A quick decrease in voltage and current was observed after midday, which is in agreement with the previous effect of cloud in reducing solar panel output [27]. Given that the drastic changes in the weather accompanied by the limited data on the environmental variables were recorded, the statistical analysis performed did not find any significant effect of the variables on the lamp performance ( $p>0.05)$.

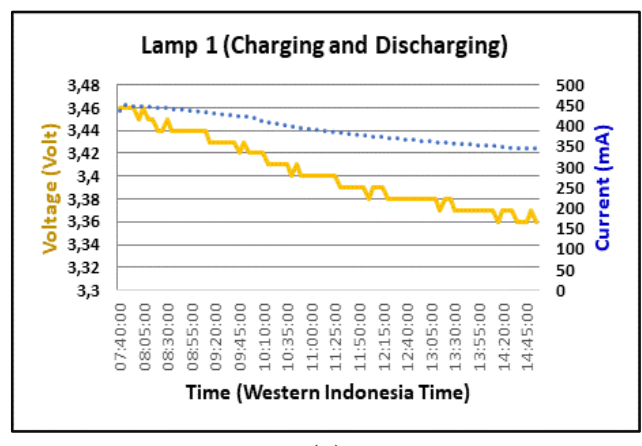

(a)

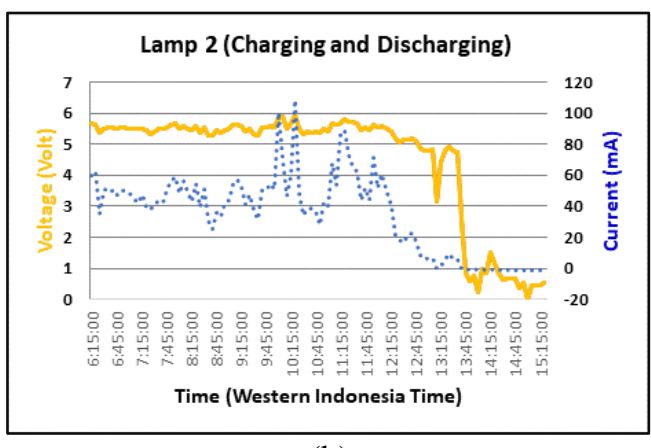

(b)

Figure 3. Results of the testing during the first field experiment at Lembang; (a) lamp 1, (b) lamp 2

\subsection{Second field experiment at Ciwidey, West Java}

In the second field experiment, five prototypes were tested, and three of them are reported in this article. The weather dominated by cloudy and light showers followed by an error in environmental variable measurement instrument resulted in data that did not show any significant correlation with the solar-powered lamp performance ( $\mathrm{p}>0.05)$. The testing of lamp 1 at the second field experiment began at $19.20 \mathrm{WIB}$ in Ciwidey with an initial battery voltage of $3.39 \mathrm{~V}$ and a current of $247.5 \mathrm{~mA}$. In this experiment session, only the discharging process was performed because the test was at night. The telescopic lamp could last for $11 \mathrm{~h}$ 18 min with a remaining battery voltage of $3.26 \mathrm{~V}$ and a residual current of $171 \mathrm{~mA}$. The changes in voltage and current during the testing of lamp 1 are depicted in Figure 4 (a). The voltage and current decreased gradually during the period of discharging testing. Yellow lines represent voltage, and dotted blue lines represent current. A gradual decrease in voltage and current was observed during the discharging processes in the evening testing.

The testing of telescopic lamp 2 during the second field experiment was started at 00:22 WIB midnight with an initial battery voltage of $3.4 \mathrm{~V}$ and a current of $277.9 \mathrm{~mA}$. The lamp was observed to last for approximately $6 \mathrm{~h} 22 \mathrm{~min}$ and left a voltage of $3.39 \mathrm{~V}$ and a current of $246.7 \mathrm{~mA}$. The changes in voltage and current during the testing of lamp 2 are shown in Figure 4 (b). For the daytime testing session, the third 
telescopic lamp test of the second field experiment location started in the morning at 6:40 WIB with an initial battery voltage of $5.53 \mathrm{~V}$ and a current of $23.6 \mathrm{~mA}$. From this field experiment session, the telescopic lamp was found to last for more than $11 \mathrm{~h}$ and left a voltage of $0.14 \mathrm{~V}$ and a current of $1.1 \mathrm{~mA}$. The changes in voltage and current during the testing of lamp 3 are shown in Figure 5 (a). A drastic decrease in solar irradiance was observed in the afternoon, especially after 1:00 PM that made drastic drop in voltage and current. Yellow lines represent voltage, and dotted blue lines represent current. The lower solar irradiance in the afternoon resulted in the drastic drop in voltage and current shown in Figure 5 (a), which resembles that in Figure 3 (b). A gradual decrease in voltage and current was observed during the discharging processes shown in Figure 5 (b), which is similar to those in Figures 4 (a) and (b). The night session of third lamp test was started in the evening at 19:20 WIB with an initial battery voltage of $3.2 \mathrm{~V}$ and a current of $501.5 \mathrm{~mA}$. The lamp was found to last for approximately $12 \mathrm{~h} 2 \mathrm{~min}$ and left a voltage of $2.83 \mathrm{~V}$ and a current of 67.3 $\mathrm{mA}$. The changes in voltage and current during the continued testing of lamp 3 are shown in Figure 5 (b). The figure shows that a faster drop occurred approximately in the last $3 \mathrm{~h}$ of the experiment.

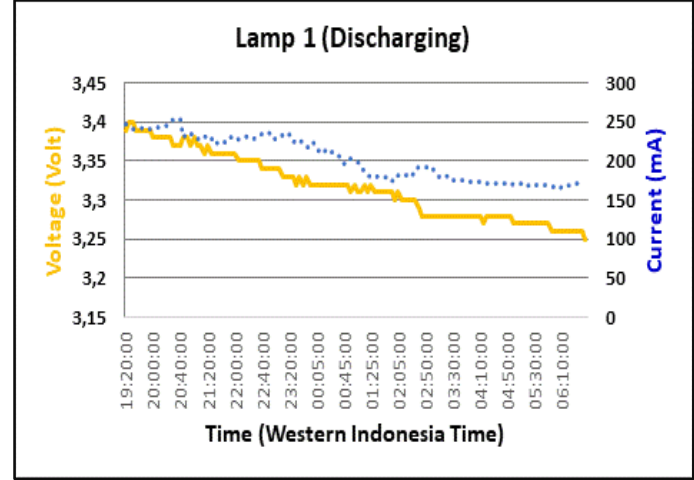

(a)

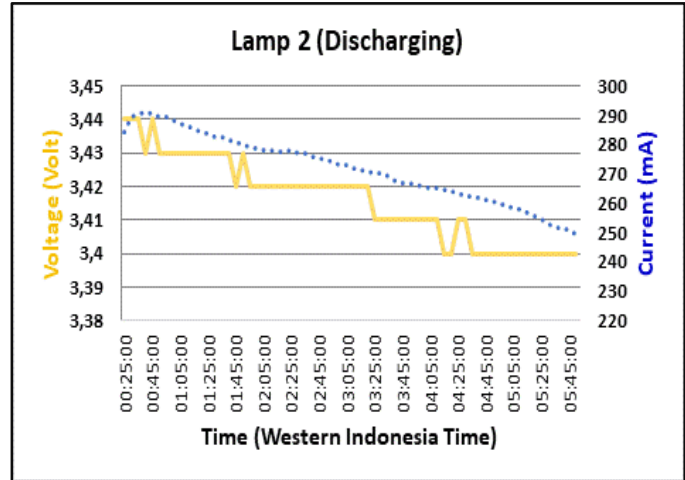

(b)

Figure 4. Results of the testing during the second field experiment at Ciwidey; (a) lamp 1, (b) lamp 2

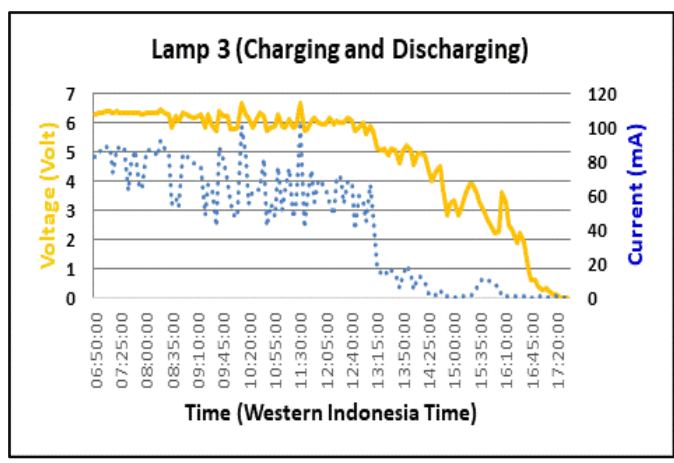

(a)

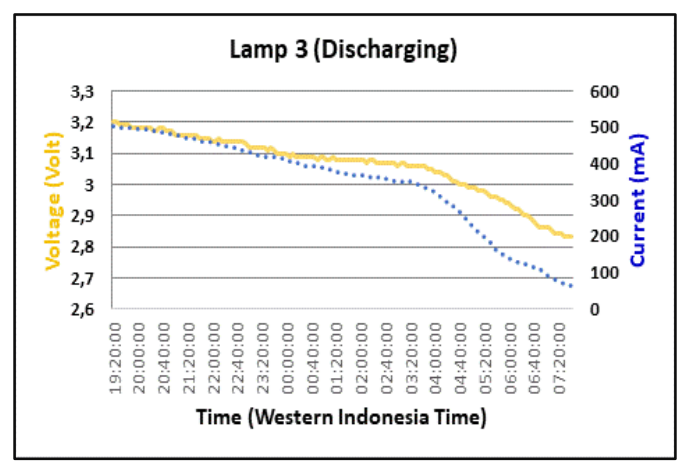

(b)

Figure 5. Results of the testing of lamp 3 during the second field experiment at Ciwidey; (a) daytime session, (b) night session

\subsection{Third field experiment at Lembang, West Java}

The weather during the experiment was clear all day. As shown in Figure 6 (a), the range of solar irradiance was between $460 \mathrm{~W} / \mathrm{m}^{2}$ measured late before sunset and $1240 \mathrm{~W} / \mathrm{m}^{2}$ measured at midday, with an average solar irradiance of $1001 \mathrm{~W} / \mathrm{m}^{2}$. The peak solar irradiance was found to be even greater than that of the previous experiment at Ayer Island. Figure 6 (b) shows the humidity was between $13.5 \%$ measured during midday and $40.3 \%$ measured before sunset, with an average humidity of $26.8 \%$. The level of humidity was lower than those in the three previous experiments. The surface temperature was measured to have a range between $28^{\circ} \mathrm{C}$ and $41.6^{\circ} \mathrm{C}$ with an average of $31.6^{\circ} \mathrm{C}$, whereas the range of the ambient temperature was measured between $26^{\circ} \mathrm{C}$ and $27^{\circ} \mathrm{C}$, with an average of $26.7^{\circ} \mathrm{C}$. The highest temperature was observed to occur at midday, and the lowest temperature was measured before sunset. The wind speed was found to be 
relatively low with an average speed of $0.7 \mathrm{~m} / \mathrm{s}$ given that the site of the field experiment was surrounded by trees and several buildings.

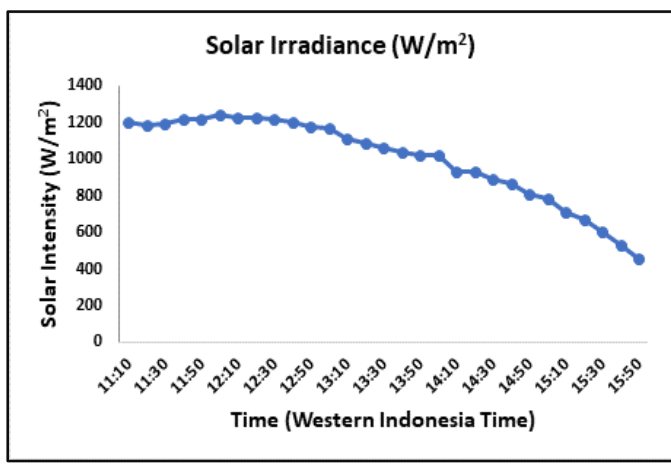

(a)

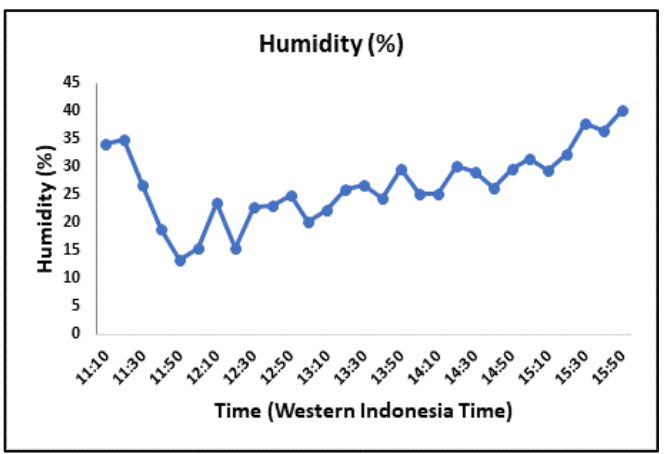

(b)

Figure 6. Solar irradiance; (a) humidity, (b) during the fourth field experiment at Lembang in August 2020

Figures 7 (a)-(b) illustrates that, in the comparison between the voltage measured between the solar panel and the circuit (Vin) and the voltage measured between the circuit and the battery (Vout), the latter was always lower than the former. Such a condition was also observed in the comparison between the electric current between the solar panel and the circuit (Iin) and the voltage measured between the circuit and the battery (Iout). The range of Vin was between 4.78 and $5.15 \mathrm{~V}$, with an average of $4.86 \mathrm{~V}$, whereas the range of Vout was between 3.47 and $3.75 \mathrm{~V}$, with an average of 3.61 V. Statistical analyses using Spearman's rank order correlation revealed that $\mathrm{Vin}$ had negative correlation with solar panel temperature ( $\mathrm{rs}=-0.495$, $\mathrm{p}=0.006)$ and ambient temperature $(\mathrm{rs}=-0.425, \mathrm{p}=0.021)$ but positive correlation with humidity ( $\mathrm{rs}=0.379$, $\mathrm{p}=0.043)$. In the meantime, Vout had a positive correlation with ambient temperature $(\mathrm{rs}=0.805, \mathrm{p}=0.000)$. The data of the electric current showed greater fluctuation than those of the voltages. The range of Iin was between 0.26 and $0.4 \mathrm{~A}$, with an average of $0.32 \mathrm{~A}$, whereas the range of Iout was between 0.04 and $0.35 \mathrm{~A}$, with an average of 0.23 A. Similar to the voltage data, the current data were not normally distributed. Therefore, non-parametric statistical analysis in the form of Spearman's rank order correlation was also used. Iin had positive correlation with solar irradiance $(r s=0.452, p=0.014)$ and ambient temperature $(r s=0.575$, $\mathrm{p}=0.000)$ but negative correlation with humidity $(\mathrm{rs}=-0.542, \mathrm{p}=0.002)$. Iout had positive correlation with solar irradiance $(\mathrm{rs}=0.833, \mathrm{p}=0.000)$, solar panel temperature $(\mathrm{rs}=0.623, \mathrm{p}=0.000)$ and wind speed $(\mathrm{rs}=0.385$, $\mathrm{p}=0.039)$. However, it had negative correlation with humidity $(\mathrm{rs}=-0.702, \mathrm{p}=0.000)$.

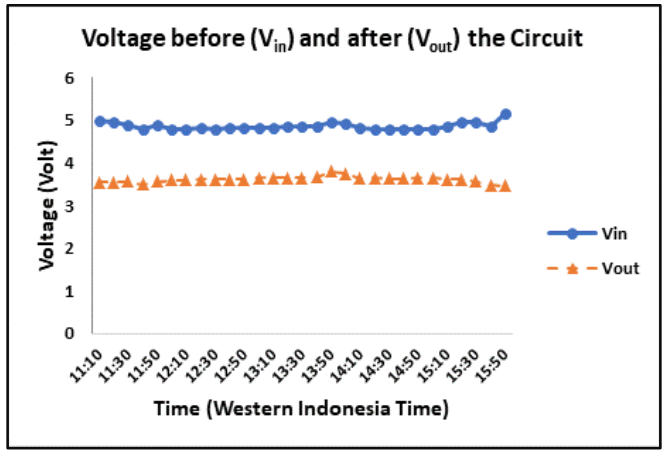

(a)

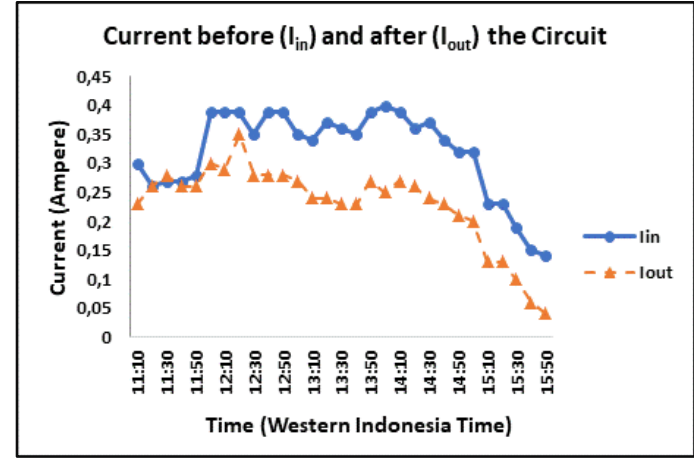

(b)

Figure 7. Results of the testing of lamp during the fourth field experiment during daytime session, (a) voltage before (Vin) and after (Vout) the circuit, (b) current before (Iin) and after (Iout) the circuit 
The fluctuation of the electric power is affected by the fluctuation of the voltage and the current, with the latter having a greater effect as proven by the resemblance in the line graph shown in Figures 8 (a)(b). The calculated electrical power between the solar panel and the circuit (Pin) was found to have a range between 0.721 and $1.94 \mathrm{~W}$ with an average of $1.55 \mathrm{~W}$, whereas the calculated electrical power between the circuit and the battery (Pout) had a range between $0.21 \mathrm{~W}$ and $1.26 \mathrm{~W}$ with an average of $0.83 \mathrm{~W}$. Pin showed significant correlation in the form of positive correlation with solar irradiance $(\mathrm{rs}=0.418, \mathrm{p}=0.024)$ and ambient temperature ( $\mathrm{rs}=0.597, \mathrm{p}=0.001)$ and negative correlation with humidity $(\mathrm{rs}=-0.513, \mathrm{p}=0.004)$. Pout had positive correlation with solar irradiance $(\mathrm{rs}=0.785, \mathrm{p}=0.000)$ and solar panel surface temperature ( $\mathrm{rs}=0.562, \mathrm{p}=0.002$ ) but negative correlation with humidity ( $\mathrm{r}=-0.684, \mathrm{p}=0.000)$. Charging efficiency was calculated from the ratio between Pin and Pout. The efficiency ranged between $19.25 \%$ (before sunset) and $75.34 \%$ (at midday) when the solar irradiance was at its peak accompanied by the lowest level of humidity. The average efficiency was calculated at $52.49 \%$, a greater number than all the previous experiments carried out during the rainy season. The efficiency had positive correlation with solar irradiance ( $\mathrm{rs}=0.853, \mathrm{p}=0.000)$ and solar panel surface temperature $(\mathrm{rs}=0.613, \mathrm{p}=0.000)$ but negative correlation with humidity $(\mathrm{rs}=-0.644$, $\mathrm{p}=0.000)$.

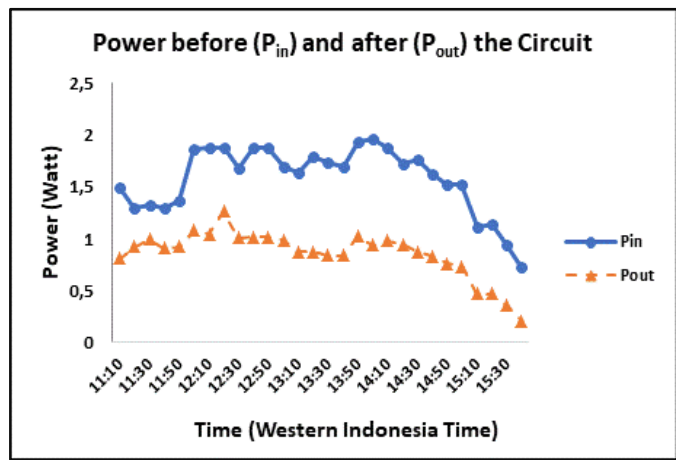

(a)

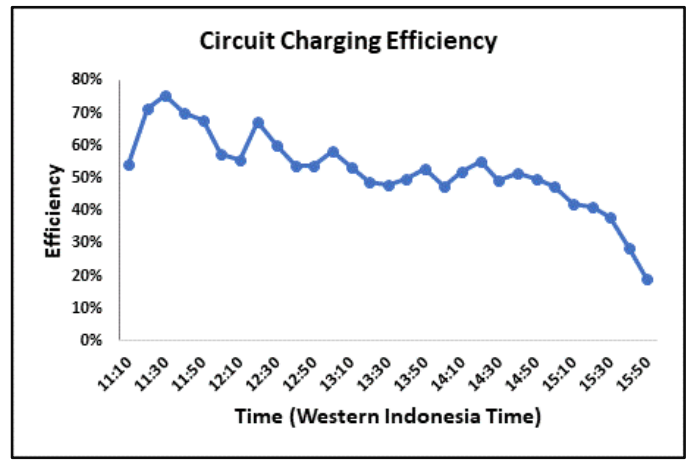

(b)

Figure 8. Electrical power changes of the lamp during the fourth field experiment during daytime session, (a) power before (Pin) and after (Pout) the circuit, (b) the circuit charging efficiency measured from Pin and Pout

\section{DISCUSSION}

\subsection{The effects of environmental variables on the solar-powered lamp performance}

From the field experiments, the environmental metre only successfully recorded a larger amount of data in the first and fourth experiments, both were conducted at Lembang, West Java. Variables such as solar irradiance, temperature and humidity affect solar-powered electricity generation [33]. In this study, the problem during data collection leads to insufficient data for statistical analysis. Only the first and fourth experiments provided sufficient environmental variables data. However, the statistical analysis of the first experiment did not show any significant correlation between the environmental variables and the lamp performance $(p>0.05)$. The first experiment was conducted during the rainy season in the mountain area popular for a long and humid tropical mountain rain. Thus, the changes in the weather from clear sky to cloudy followed by light showers or even rain resulted in the greater fluctuation in the environmental variables data. Such an environment is probably not an appropriate place for solar-based electrical power generation. On the contrary, the fourth field experiment was conducted at the same place during the dry season with much greater sunlight intensity and lower humidity. As such, the experiment successfully revealed the effects of environmental variables on the solar-powered lamp performance.

\subsubsection{Sunlight intensity effect}

Sunlight intensity was found to positively affect the electrical current and power before and after the circuit and the efficiency. Greater solar irradiance will increase these performance variables, a confirmation to the statement that electric energy generation is nearly proportional to the solar irradiation level. Notably, voltage is insignificantly affected by the solar irradiation level probably due to temperature. The temperature measured from the solar panel indicated a negative correlation with voltage before the circuit and a positive correlation with the electrical current and power after the circuit and efficiency. The ambient temperature indicated a negative correlation with the voltage before the circuit and a positive correlation with the voltage after the circuit, the electrical current and power before the circuit and efficiency. 


\subsubsection{Ambient temperature effect}

Ambient temperature has been reported to decrease power generation and overall efficiency under higher temperature [33], [34]. The findings of the current study reveal that such condition only occurs on the voltage, whilst other performance variables are in contradictory with the previous studies. However, the maximum temperature investigated in the previous studies was much higher than that in this study. Therefore, the effects of the temperature probably also differ. Higher ambient temperature and greater solar irradiance will increase the solar panel temperature, which will decrease the voltage and increase the electrical current. Ultimately, the electrical power generated by the system will increase. Higher humidity level corresponds to higher voltage before the circuit and lower current before and after the circuit, electrical power before and after the circuit and efficiency. A previous study reported that humidity decreases the voltage, current and power [29]. In the present study, the findings are in agreement with those in the previous study, except the voltage before the circuit. The humidity actually affects the circuit and other parts after the circuit to a greater degree than the solar panels.

\subsection{System fficiency}

The suggested circuit efficiency or fill factor was up to $80 \%$ [30]. The peak efficiency calculated during the fourth experiment during the dry season was $75.34 \%$ with an average of $52.59 \%$, which is much greater than those of all the three earlier field experiments. The results indicated that the performance of the solar-powered telescopic lamp is actually only slightly lower than the reference when the weather and the environment support its operation, especially during the dry season in Indonesia. As depicted in Table 3, the compared references mostly have circuit efficiency in the range of the designed lamp, especially when the solar irradiance and cell temperature are at the same level. However, the condition that Indonesia has rainy and dry seasons, each for around six months, should be considered for the future development of the lamp.

Table 3. Data of fill factor from various references

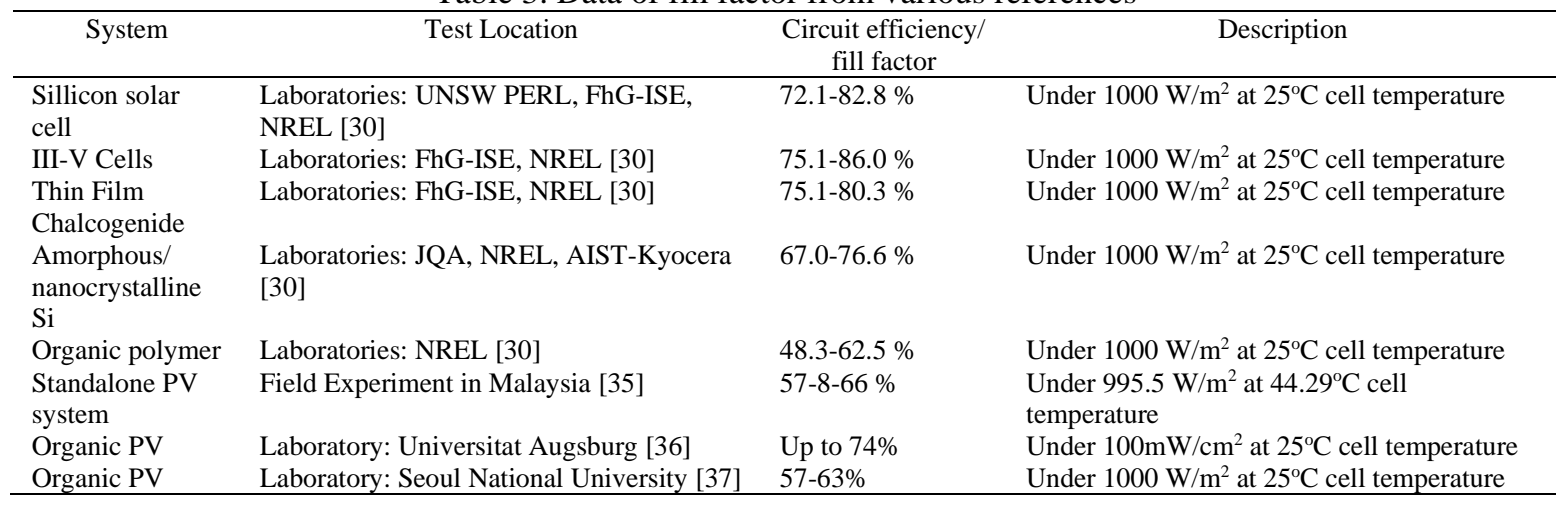

\subsection{Efficiency improvement techniques for future development 4.3.1. Solar power tracking system}

A solar power tracking system to automatically direct the solar panel towards the most optimal direction of the sunlight has been developed by another group of researchers in our research centre [38]. This system may be an option of technology to be incorporated in the future design of the telescopic lamps to optimise solar energy harvesting. Further development of the system to track the maximum power point has included a proportional-integral (PI) controller based on fuzzy logic [39]. PI-based maximum power point tracking (MPPT) has been suggested to be the most appropriate for low-cost applications as it is not only low cost but also easy and simple [40]. Artificial neural network is considered to provide the best efficiency in MPPT and can predict the generated electricity beforehand [41]. However, it is more costly because of the additional sensors, such as temperature and irradiance sensors [40]. As such, it is probably more applicable in a larger solar energy harvesting system. Another approach is the application of artificial intelligence to predict the weather $24 \mathrm{~h}$ ahead by optimising the information of weather forecasts and input power [42]. In general, solar power prediction is complex because it involves the PV system and environment variables. Therefore, various AI-based prediction models should be analysed to select the best model for different application scenarios [43]. 


\subsubsection{The cooling system}

Other than solar tracking, another technology considered for future inclusion in the re-designed solarpowered telescopic lamp is the cooling system given that Indonesia lies in the tropical climate. The hot and humid climate has been worsening due to global warming, and this situation increases the necessities for the cooling system. In general, cooling systems have two types: passive and active cooling systems. Passive cooling techniques are the method to minimise heat absorption by the solar panel by transportation and dissipation of heat to the environment without any power consumption [44], [45]. Passive cooling techniques include phase change material (PCM)-based cooling techniques, air-based passive cooling techniques and liquid-based passive cooling techniques [45]. Amongst the three methods, the PCM-based cooling technique is suggested to be the most harmful to the environment, whilst the air-based cooling technique is considered the most eco-friendly. The active cooling technique is a method for cooling the solar panel that requires continuous power consumption for its operation [44], [46]. Active cooling techniques include air- and water-based active cooling techniques, where the latter is considered to be more eco-friendly than the former [46]. Active cooling techniques offer greater efficiency; however, the cost is more expensive. The positive and negative aspects of the cooling techniques should be studied thoroughly before selecting the most applicable technique.

\section{CONCLUSIONS}

From testing by comparing the charging power of the incoming solar cell with the real power received by the battery after passing through the electronic circuit (comparison between charging power before and after passing the circuit), a solar panel power is found to be lost when measured in the battery. The efficiency of the solar cells is still low compared with some references when the weather is cloudy or rainy. However, when the solar irradiance is higher during the dry season, the efficiency is close to the maximum value suggested by the references. Improving the efficiency of solar energy harvesting by the application technologies such as MPPT system or solar panel cooling system can be considered for further development of the lamp. The most important aspects for a product that is intended to be used by people mostly in remote areas with limited technical support are usability and cost. As such, the next step after field tests will be testing by the intended users to gain an insight into any potential problem during the adoption process of the lamp by the future users. Research on user experience when using the product on the field should be conducted. Any new technology inclusion should not neglect the consideration of practicality and cost efficiency given that some of the potential users are probably unfamiliar with high-tech products and have limited financial capability to afford the lamp.

\section{ACKNOWLEDGEMENTS}

The author would like to thank the research grant received from the Indonesian Ministry of Research, Technology, and Higher Education with the funding scheme of Industrial Technology Development Program (Program Percepatan Teknologi Industri/PPTI), grant number 07/II/PPK/E/E4/2018.

\section{DECLARATIONS}

All authors contributed equally as the main contributor of this paper. All authors read and approved the final paper.

\section{REFERENCES}

[1] Statistics Indonesia, "Indonesia Electrification Ratio," 2017. [Online]. Availabe: https://www.bps.go.id/indikator/indikator/view_data/0000/data/1155/sdgs_7/1 (Accessed Apr. 01, 2020).

[2] A. J. Veldhuis and A. H. M. E. Reinders, "Reviewing the potential and cost-effectiveness of grid-connected solar PV in Indonesia on a provincial level," Renewable and Sustainable Energy Reviews, vol. 27, pp. 315-324, 2013, doi: 10.1016/j.rser.2013.06.010.

[3] M. H. Smith, K. Hargroves, and Cheryl Desha, "Cents and Sustainability," First Edit. London: Earthscan Ltd, 2010.

[4] A. Halim, A. Fudholi, S. Phillips, and K. Sopian, "Review on Optimised Configuration of Hybrid Solar-PV Diesel System for Off-Grid Rural Electrification.," International Journal of Power Electronics and Drive Systems (IJPEDS), vol. 9, no. 3, p. 1374, 2018, doi: 10.11591/ijpeds.v9.i3.pp1374-1380.

[5] D. Sattianadan, G. R. P. Kumar, R. Sridhar, K. V. Reddy, B. S. U. Reddy, and P. Mamatha, "Investigation of low voltage dc microgrid using sliding mode control," International Journal of Power Electronics and Drive Systems, vol. 11, no. 4, pp. 2030-2037, 2020, doi: 10.11591/ijpeds.v11.i4.pp2030-2037.

[6] R. H. G. Tan, C. B. Chuin, and S. G. Solanki, "Modeling of single phase off-grid inverter for small standalone system applications," International Journal of Power Electronics and Drive Systems, vol. 11, no. 3, pp. 1398-1405, 2020, doi: 10.11591/ijpeds.v11.i3.pp1398-1405. 
[7] A. J. Veldhuis and A. H. M. E. Reinders, "Reviewing the potential and cost-effectiveness of off-grid PV systems in Indonesia on a provincial level," Renewable and Sustainable Energy Reviews, vol. 52, pp. 757-769, 2015.

[8] C. U. Cassiani Ortiz, J. E. Candelo-Becerra, and F. E. Hoyos Velasco, "Electricity market strategies applied to microgrid development," International Journal of Power Electronics and Drive Systems, vol. 11, no. 1, pp. 530546, 2020, doi: 10.11591/ijpeds.v11.i1.pp530-546.

[9] A. Wangsupphaphol and S. Chaitusaney, "A simple levelized cost of electricity for ev charging with pv and battery energy storage system: Thailand case study," International Journal of Power Electronics and Drive Systems, vol. 11, no. 4, pp. 2223-2230, 2020, doi: 10.11591/IJPEDS.V11.I4.PP2223-2230.

[10] Statistics Indonesia, "Number of Villages According to Electricity Users," 2018. https://www.bps.go.id/statictable/2015/02/09/1759/banyaknya-desa-kelurahan-menurut-keberadaan-keluargapengguna-listrik-dan-sumber-penerangan-jalan-utama-desa-2014-2018-.html.

[11] Alastair Fuad-Luke, "Eco-design Handbook," First Edition London: Thames \& Hudson Ltd, 2002.

[12] T. Zhao, Z. Ju, X. Wei and X. Li, "Creative design of solar energy portable lamp based on product gene and intuition models," 2010 IEEE Int. Conf. Ind. Eng. and Eng. Manage., 2010, pp. 334-337, doi: 10.1109/IEEM.2010.5674303.

[13] Q. Wang, "The solar-powered lantern system with self-adaptive function," Proceedings of 2013 IEEE Int. Conf. Vehicular Electronics and Safety, ICVES 2013, 2013, pp. 219-223, doi: 10.1109/ICVES.2013.6619635.

[14] A. Bastian, K. Devara, S. Ramadhanty, and T. Abuzairi, "Design of portable emergency lamp utilizing thin film solar cell and inflatable case," E3S Web of Conferences, 2018, vol. 67, pp. 1-5, doi: 10.1051/e3sconf/20186701019.

[15] J. A. Snyder, "Inflatable Solar Powered Lamp," US 2015/0211695 A1, 2015.

[16] M. P. McHenry, D. Doepel, B. O. Onyango, and U. L. Opara, "Small-scale portable photovoltaic-battery-LED systems with submersible LED units to replace kerosene-based artisanal fishing lamps for sub-Saharan African lakes," Renewable Energy, vol. 62, pp. 276-284, 2014, doi: http://doi.org/10.1016/j.renene.2013.07.002 McHenry.

[17] M. H. Mubarok, "Capacities and Accountabilities of Stakeholders in Indonesia's Rural Electrification Program A View from Responsible Innovation and Learning Approaches," Thesis, Doctoral dissertation, Eindhoven University of Technology, 2017.

[18] Y. Shimomura and T. Katsuura, "Sustaining biological welfare for our future through consistent science," Journal of physiological anthropology, vol. 32, no. 1, p. 1, 2013, doi: 10.1186/1880-6805-32-1.

[19] A. Mital, A. S. Nicholson, and M. M. Ayoub, "A Guide to Manual Materials Handling," Second Edition London: Taylor \& Francis, 1997.

[20] M. Sato, "The Development of Conceptual Framework in Physiological Anthropology," Journal of Physiological Anthropology and Applied Human Science, vol. 24, no. 4, pp. 289-295, 2005, doi: 10.2114/jpa.24.289.

[21] K. Iwanaga, "The biological aspects of physiological anthropology with reference to its five keywords," Journal of physiological anthropology and applied human science, vol. 24, pp. 231-235, 2005, doi: 10.2114/jpa.24.231.

[22] S. K. Chandrasegaran et al., "The evolution, challenges, and future of knowledge representation in product design systems," CAD Computer Aided Design, vol. 45, no. 2, pp. 204-228, 2013, doi: 10.1016/j.cad.2012.08.006.

[23] Matthew Eastwood, "ECO-BRIEF The Environmental Product Life Cycle : Environmentally Friendly Design," in Proceeding-2007 IDC Sponsored by HP, 2007, pp. 1-4.

[24] NTUA, "Manual on Eco-Design and End-of-Life management of Electronic Products," 2007.

[25] E. Maris, D. Froelich, A. Aoussat, and E. Naffrechoux, "From Recycling to Eco-design," in Handbook of Recycling: State-of-the-art for Practitioners, Analysts, and Scientists, Amsterdam: Elsevier Inc., 2014, pp. 421427.

[26] M. Dang, "Potential of Solar Energy Indonesia," Researchgate Technical Report, 2017.

[27] M. Rahim, J. Yoshino, and T. Yasuda, "Evaluation of solar radiation abundance and electricity production capacity for application and development of solar energy," Int. J. Energy and Environment, vol. 3, no. 5, pp. 687-700, 2012.

[28] B. A. L. Gwandu and D. J. Creasey, "Humidity: A factor in the appropriate positioning of a photovoltaic power station," Renewable Energy, vol. 6, no. 3, pp. 313-316, 1995, doi: 10.1016/0960-1481(95)00073-S.

[29] H. A. Kazem and M. T. Chaichan, "Effect of humidity on photovoltaic performance based on experimental study," International Journal of Applied Engineering Research, vol. 10, no. 23, pp. 43572-43577, 2015.

[30] M. A. Green, K. Emery, Y. Hishikawa, and W. Warta, "Solar cell efficiency tables (version 36)," Progress in Photovoltaics: Research and Applications, vol. 18, no. 5, pp. 346-352, 2010, doi: 10.1002/pip.1021.

[31] A. Belghachi, "Theoretical Calculation of the Efficiency Limit for Solar Cells," in Solar Cells-New Approaches and Reviews, 2015, pp. 47-76.

[32] Infinitypv.com, "Solar cell efficiency," [Online]. Available: https://infinitypv.com/learn/teacher-guides/solar-cellefficiency?tmpl=print\&learn-lan= (accessed Apr. 08, 2020).

[33] N. Hamrouni, M. Jraidi, and a Chérif, "Solar radiation and ambient temperature effects on the performances of a PV pumping system," Revue des Energies Renouvelables, vol. 11, pp. 1-95, 2008.

[34] F. H. Gandoman, S. H. E. Abdel Aleem, N. Omar, A. Ahmadi, and F. Q. Alenezi, "Short-term solar power forecasting considering cloud coverage and ambient temperature variation effects," Renewable Energy, vol. 123, pp. 793-805, 2018, doi: 10.1016/j.renene.2018.02.102.

[35] A. Rivai and N. A. Rahim, "A low-cost photovoltaic (PV) array monitoring system," in CEAT 2013 - 2013 IEEE Conference on Clean Energy and Technology, 2013, pp. 169-174, doi: 10.1109/CEAT.2013.6775620.

[36] J. Wagner et al., "High fill factor and open circuit voltage in organic photovoltaic cells with diindenoperylene as donor material," Advanced Functional Materials, vol. 20, no. 24, pp. 4295-4303, 2010, doi: 10.1002/adfm.201001028. 
[37] H. S. Shim et al., "Enhancement of near-infrared absorption with high fill factor in lead phthalocyanine-based organic solar cells," Journal of Materials Chemistry, vol. 22, no. 18, pp. 9077-9081, 2012, doi: 10.1039/c2jm30417a.

[38] M. Mirdanies, R. A. Ardiansyah, H. M. Saputra, A. S. Nugraha, E. Rijanto, and A. Santoso, "Design of Control System for Solar Power Tracking Mechanism and Energy Saving Telecontrol Facility," Journal of Mechatronics, Electrical Power, and Vehicular Technology, vol. 2, no. 1, p. 31, 2012, doi: 10.14203/j.mev.2011.v2.31-40.

[39] S. Slamet, E. Rijanto, A. Nugroho, and R. A. Ghani, "A robust maximum power point tracking control for PV panel using adaptive PI controller based on fuzzy logic," TELKOMNIKA (Telecommunication Computing Electronics and Control), vol. 18, no. 6, p. 2999, 2020, doi: 10.12928/telkomnika.v18i6.17271.

[40] M. Kermadi and E. M. Berkouk, "Artificial intelligence-based maximum power point tracking controllers for Photovoltaic systems: Comparative study," Renewable and Sustainable Energy Reviews, vol. 69, no. June 2015, pp. 369-386, 2017, doi: 10.1016/j.rser.2016.11.125.

[41] E. Izgi, A. Öztopal, B. Yerli, M. K. Kaymak, and A. D. Şahin, "Short-mid-term solar power prediction by using artificial neural networks," Solar Energy, vol. 86, no. 2, pp. 725-733, 2012, doi: 10.1016/j.solener.2011.11.013.

[42] C. Chen, S. Duan, T. Cai, and B. Liu, "Online 24-h solar power forecasting based on weather type classification using artificial neural network," Solar Energy, vol. 85, no. 11, pp. 2856-2870, 2011, doi: 10.1016/j.solener.2011.08.027.

[43] H. Wang et al., "Taxonomy research of artificial intelligence for deterministic solar power forecasting," Energy Conversion and Management, vol. 214, no. April, p. 112909, 2020, doi: 10.1016/j.enconman.2020.112909.

[44] S. Kalaiselvan, V. Karthikeyan, G. Rajesh, A. Sethu Kumaran, B. Ramkiran, and P. Neelamegam, "Solar PV Active and Passive Cooling Technologies-A Review," 7th IEEE Int. Conf. on Computation of Power, Energy, Information and Communication, ICCPEIC 2018, 2018, pp. 166-169, doi: 10.1109/ICCPEIC.2018.8525185.

[45] S. Nižetić, A. M. Papadopoulos, and E. Giama, "Comprehensive analysis and general economic-environmental evaluation of cooling techniques for photovoltaic panels, Part I: Passive cooling techniques," Energy Conversion and Management, vol. 149, pp. 334-354, 2017, doi: 10.1016/j.enconman.2017.07.022.

[46] S. Nižetić, E. Giama, and A. M. Papadopoulos, "Comprehensive analysis and general economic-environmental evaluation of cooling techniques for photovoltaic panels, Part II: Active cooling techniques," Energy Conversion and Management, vol. 155, no. October 2017, pp. 301-323, 2018, doi: 10.1016/j.enconman.2017.10.071. 